6-2013

\title{
Another Look at the Collapse of Skyline Plaza at Bailey's \\ Crossroads, Virginia
}

Jeffrey Schellhammer

Brayman Construction Corporation, j_schellhammer@brayman.com

Norbert Delatte

Cleveland State University, n.delatte@csuohio.edu

Paul A. Bosela

Cleveland State University, p.bosela@csuohio.edu

Follow this and additional works at: https://engagedscholarship.csuohio.edu/encee_facpub

Part of the Civil Engineering Commons, and the Structural Engineering Commons

How does access to this work benefit you? Let us know!

\section{Publisher's Statement}

(c) ASCE

\section{Original Citation}

Schellhammer, J., Delatte, N., and Bosela, P. (2013). "Another Look at the Collapse of Skyline Plaza at Bailey's Crossroads, Virginia." J.Perform.Constr.Facil., 27(3), 354-361.

This Article is brought to you for free and open access by the Civil and Environmental Engineering at EngagedScholarship@CSU. It has been accepted for inclusion in Civil and Environmental Engineering Faculty Publications by an authorized administrator of EngagedScholarship@CSU. For more information, please contact library.es@csuohio.edu. 


\title{
Another Look at the Collapse of Skyline Plaza at Bailey's Crossroads, Virginia
}

\author{
Jeffrey Schellhammer ${ }^{1}$; Norbert J. Delatte, F.ASCE ${ }^{2}$; and Paul A. Bosela, F.ASCE ${ }^{3}$
}

\section{Introduction}

On March 2, 1973, the Skyline Plaza apartment building in Bailey's Crossroads, Virginia collapsed while under construction. The collapse extended vertically through the building, from the 24th floor to the ground, leaving an appearance of the structure as two different high-rise buildings with a gap between them. The collapse tore a $18-\mathrm{m}(60-\mathrm{ft})$ wide gap through the building all the way to the ground. At the time of the collapse, two practically identical RC towers had already been built (Kaminetzky 1991, p. 64). Fig. 1 shows an aerial photograph of the structure taken shortly before the collapse, at about 11 a.m. on the same day. The collapse occurred at about 2:30 p.m. (Leyendecker and Fattal 1977, p. 2). The collapsed structure is shown in Figs. 2-4.

The American Concrete Institute's (ACI) Formwork for Concrete (Hurd 2005, pp. 2-2-2-3) cites this case as a "tragic example of too-early shore removal." This case study reviews the available published information on the case to determine what lessons can be learned. The case is suitable for inclusion in variety of courses in the civil engineering and construction curriculum.

\section{Description of the Structure}

The 26-story apartment building was part of a $\$ 200$ million residential project (Carper 1997, p. 243). The floor plan is shown in Fig. 5. The building that collapsed is on the left side of Fig. 5, with a parking garage extending to the right. The $118-$ by $23-\mathrm{m}$ (386- by 76- $\mathrm{ft}$ ) building was to be built at a pace of one floor per week (Delatte 2009 , p. 145). Each floor was to be placed in four separate sections with a construction joint in the middle, between sections two and three.

The completed structure was to be 26 -stories tall. The building was to include the 26 stories, a penthouse, and a 4-story basement. Each floor was to be $3 \mathrm{~m}$ ( $9 \mathrm{ft}$ ) from top of slab to top of slab, and the basement was to be a total of $14 \mathrm{~m}$ ( $40 \mathrm{ft})$ with the four levels varying in height because of mechanical equipment. The first floor elevation was to be the same as the roof of the parking garage, which was to be a green, landscaped area. The building was designed to the 1963 edition of the ACI Building Code Requirements for Reinforced Concrete ACI 318-63 (Leyendecker and Fattal 1977, p. 5; ACI 1963).

Two different foundation types were used in the construction of the complex. The apartment building used a $1.2-\mathrm{m}(4-\mathrm{ft})$ thick mattype foundation, whereas the parking garage used columns on footings. The column layout of the apartment building, shown in Fig. 5, was the same throughout the structure. The size and strength of concrete differed with respect to the height of the structure. The compressive strength of the normal weight concrete was to be 34.5 $\mathrm{MPa}(5,000 \mathrm{psi})$ for the columns from the foundation to the seventh floor, $27.6 \mathrm{MPa}(4,000 \mathrm{psi})$ from the seventh floor to the seventeenth floor, and $20.7 \mathrm{MPa}(3,000 \mathrm{psi})$ from the seventeenth floor to the top of the structure. The floor slabs used sand-lightweight concrete with a compressive strength of $20.7 \mathrm{MPa}$ (3,000 psi) (Leyendecker and Fattal 1977, pp. 5-7).

Both structures used a flat-plate type of construction. According to Wight and MagGregor (2002, p. 6), flat plates are "of uniform 


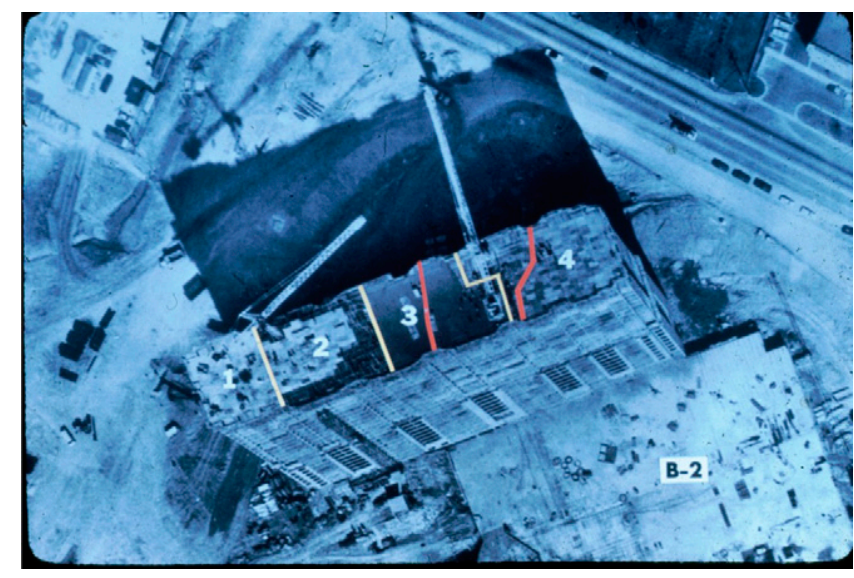

Fig. 1. Aerial photograph of the structure shortly before the collapse (courtesy of NIST)

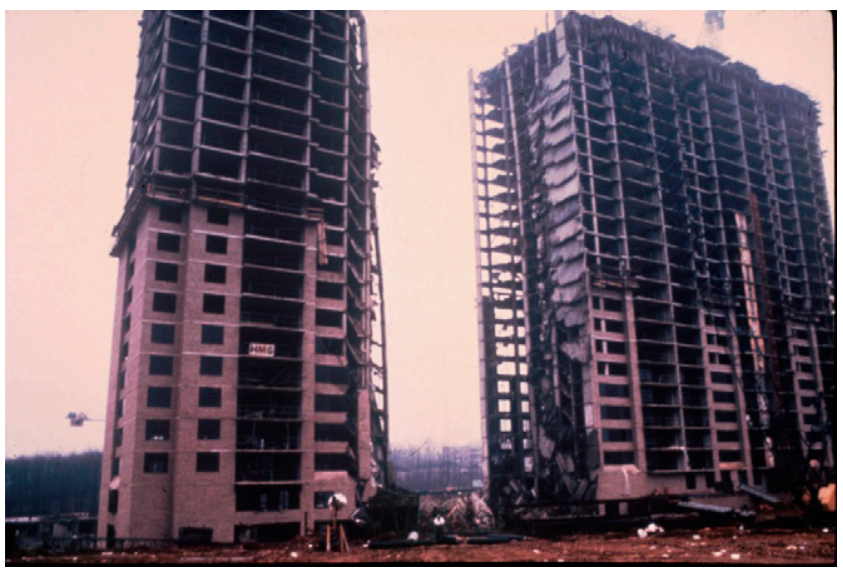

Fig. 2. The collapsed structure (courtesy of NIST)

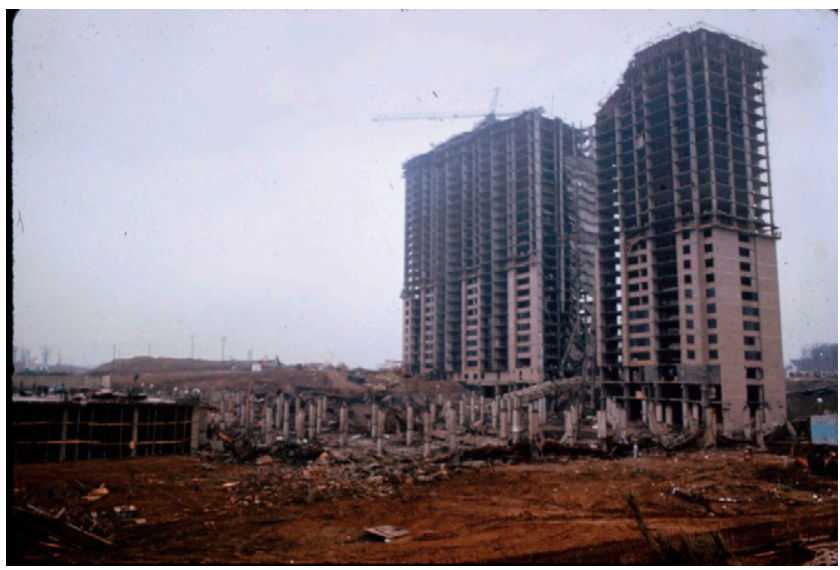

Fig. 3. Another view of the collapsed structure (courtesy of NIST)

thickness throughout without drop panels or column capitals. . Flatplate floors are widely used in apartments because the underside of the slab is flat and hence can be used as the ceiling of the room below. Of equal importance, the forming for a flat plate is generally cheaper than that for flat slabs with drop panels or for one-way slab-andbeam floors." This meant that the slab itself carried the bending and

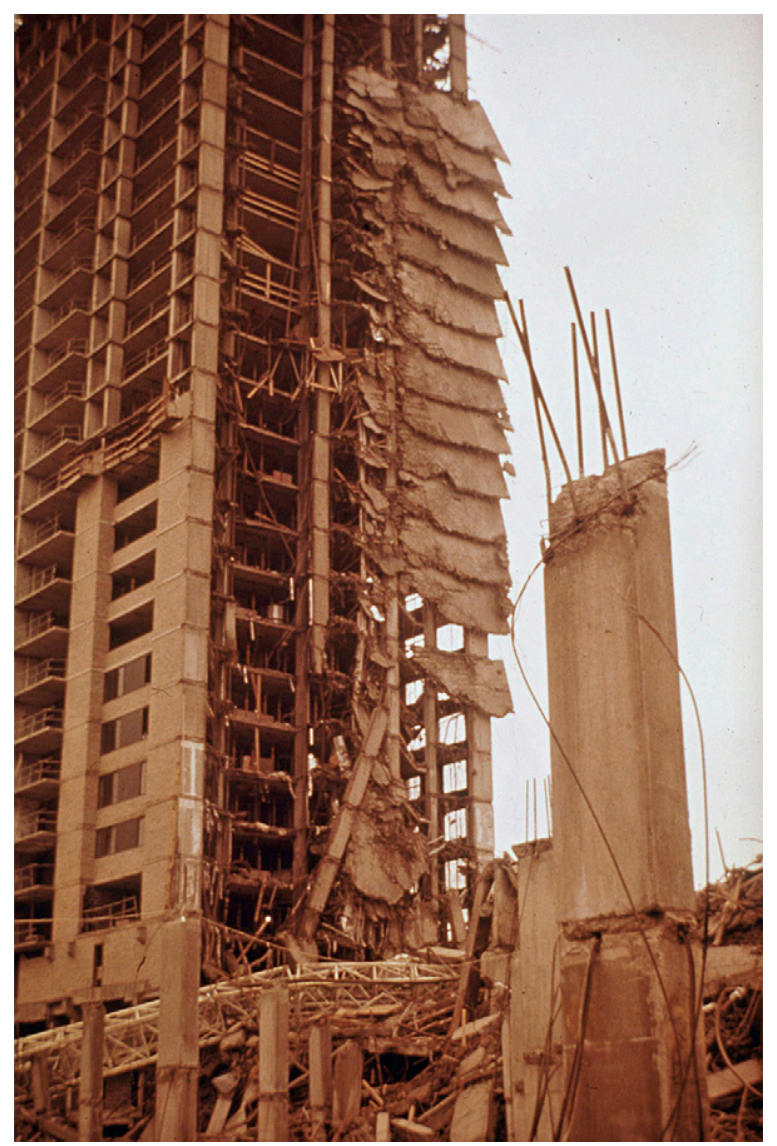

Fig. 4. Close-up view of the collapsed structure (courtesy of NIST)

shear stresses produced from the respective floor dead and live loads, without reinforcing beams.

\section{Collapse}

Shortly after lunch, some workers observed slab deflections of approximately $150-600 \mathrm{~mm}$ ( 6 in. to $2 \mathrm{ft}$ ) for both the $23 \mathrm{rd}$ floor slab and the freshly placed 24 th floor slab. The freshly placed section of the 24th floor slab then fell onto the 23rd floor slab, starting a collapse that continued all the way to the foundation (Schlager 1994). Schousboe (1976) described in detail the construction activities that occurred on the day of collapse and the condition of the building and the parking garage just before the event. The building's collapse removed the edge support from the parking garage, and falling debris triggered the failure of the garage.

The collapse killed 14 workers and injured 34 (Carino et al. 1983, p. 35). The area that collapsed is designated as area 3 in Fig. 1. This area also contained a crane; as a result, there was a question as to whether the crane fell and initiated the collapse, or if it just came down with the rest of the building. Once the section of the apartment building collapsed, the failure propagated horizontally through the attached parking garage. Of the workers killed, 10 were in the tower and four in the garage (Leyendecker and Fattal 1977, p. 2).

On March 3, 1973, the New York Times noted, "Six Killed as a Crane Drops Through Virginia Building." The article stated that, "Six persons were killed, 34 injured and 14 were reported missing today in the collapse of a partly completed high-rise apartment building in this suburb of Washington DC." This article was published the day after the collapse. The initial hypothesis was that the 


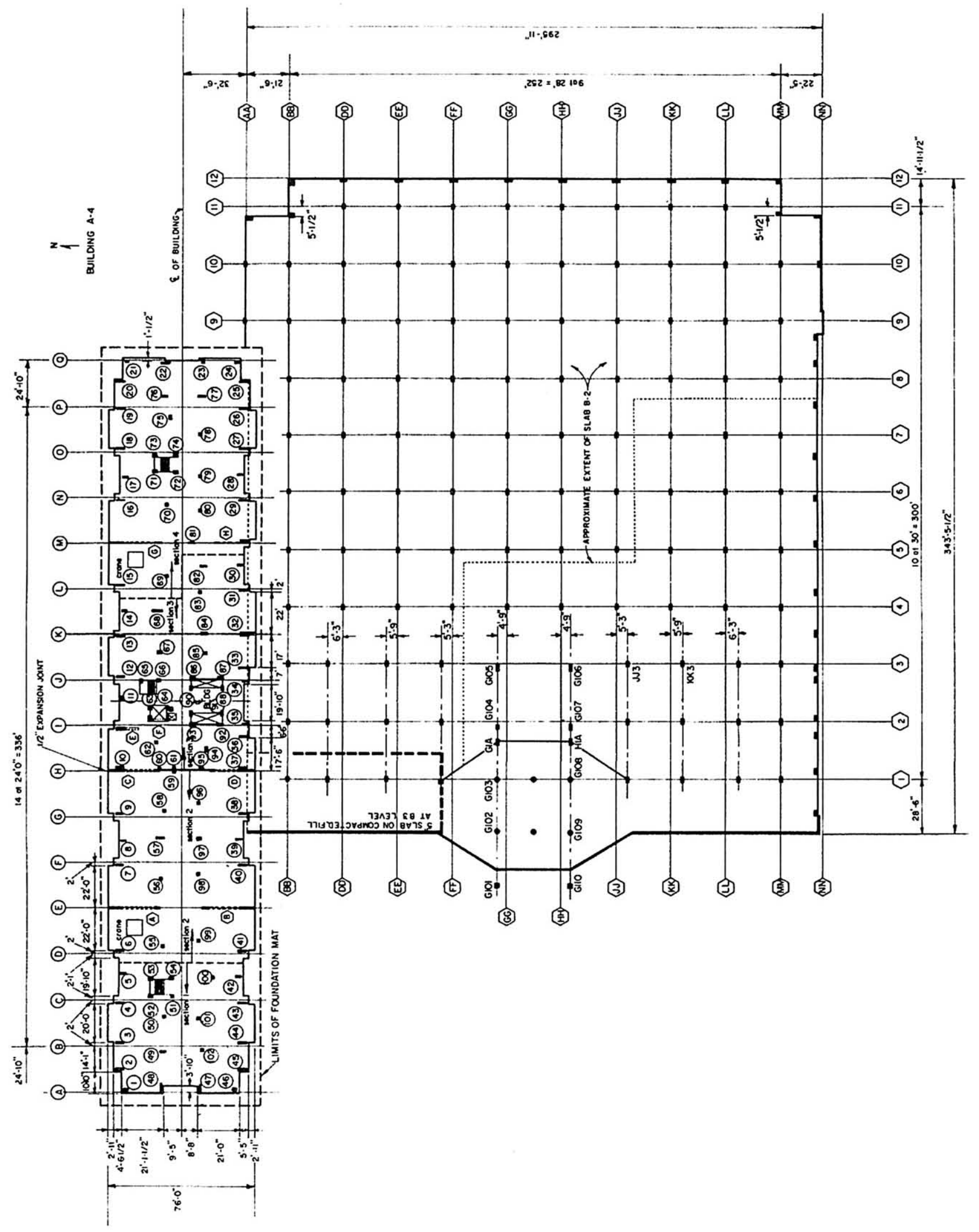

Fig. 5. Plan view of the Skyline Plaza Apartment Building and parking garage (Leyendecker and Fattal 1977, p. 6)

crane itself was the cause for the collapse. The article stated, "The falling crane broke through the top floors, its weight carrying with it layer after layer of concrete to the ground in a 'domino effect,' Lieutenant Diezel said. 'It made a terrible impact, almost like a bomb'." The article also stated that the impact of the collapse caused the adjoining parking garage to collapse, and that most of the workers that were onsite were working on the garage. In conclusion, the article states that, "there were more than 200 workers at the site 
when the collapse occurred, at 2:30 p.m. Some 24 floors of the building had already been completed, and the 10 bottom floors had been faced with brick" ("Six killed" 1973).

The next day, another article was published in the New York Times stating, "Building Wreckage Will be Dismantled." This article stated that the building "was sliced in two yesterday when a crane broke through and crashed floor by floor to the ground in a mass of broken concrete and twisted metal. Of 337 men working in the building, five are known dead and 34 were injured." ("Building wreckage" 1973).

\section{National Bureau of Standards Investigation}

Shortly after the collapse, the Occupational Safety and Health Administration (OSHA) arrived on the site to investigate. On March 5, OSHA requested technical assistance from the National Bureau of Standards [NBS; now the National Institute of Standards and Technology (NIST)]. The investigators did not gain access to the building until March 5th. This meant that the eastern part of the structure had already been demolished, but the NBS report does not indicate that this demolition or any of the rescue operations had any effect on the investigation (Leyendecker and Fattal 1977, pp. 2-7).

The NBS team was asked to answer three questions-the cause of the accident, whether there had been violations of OSHA safety standards, and if any violations contributed to the collapse. The NBS investigators reviewed records from on-site inspections, OSHA case records, structural, architectural, and shop drawings, and the results of tests on concrete core samples (Carino et al. 1983, pp. 35-36).

At the time, NBS regularly carried out building failure investigations when requested by another agency such as OSHA. "The bureau limits its investigations to technical matters. It does not attempt to trace the source of technical errors or assign blame. The bureau sees these technical studies as compatible with its research, particularly its development of building design criteria for use by the voluntary code groups" ("Bureau's failure" 1981).

\section{Construction Process}

Typical floors in the apartment building were placed in four sections with an expected speed of one section per day. At such a rate, the construction crew could finish one floor per week with 1 day left for possible weather delays (Leyendecker and Fattal 1977, p. 7).

Although the previous pace of construction had been one floor per week, near the end of February, the pace accelerated to almost twice that rate. As a result, when the concrete was being placed for the 24th floor, the 23rd floor slab was only 4 days old instead of 7 days old (Schousboe 1976; Schlager 1994).

\section{Formwork and Shoring}

The NBS team quickly determined that the condition of the formwork would be important for the investigation. The ACI Guide to Formwork for Concrete (ACI 2004) provides the following definitions for form, formwork, reshores, and shores:

"form-a temporary structure or mold for the support of concrete while it is setting and gaining sufficient strength to be selfsupporting.

formwork-total system of support for freshly placed concrete, including the mold or sheathing that contacts the concrete and all supporting members, hardware, and necessary bracing.

reshores - shores placed snugly under a stripped concrete slab or other structural member after the original forms and shores have been removed from a large area, requiring the new slab or structural member to deflect and support its own weight and existing construction loads to be applied before installation of the reshores.

shores-vertical or inclined support members designed to carry the weight of the formwork, concrete, and construction loads above."

To determine whether premature removal of shoring or failure to install reshoring had caused the collapse, it was necessary to determine what formwork was in place at that time. This proved difficult. Between the March 2nd collapse and the arrival of the NBS team on site, additional reshoring was placed to stabilize some parts of the building. Some of the workers' statements about the status of the shoring conflicted with each other. One worker who was installing reshores on the 21st floor claimed to have heard formwork and shoring removal on the 22 nd floor at about 2 p.m. Careful analysis of photographs taken right after the collapse showed that while full shoring remained on the $23 \mathrm{rd}$ and 24 th stories, it had nearly all been removed from the 22nd story in sections 1 and 2, but remained in section 4 . The condition of the formwork in section 3 could not be observed because nearly all of this section had collapsed. The engineer's structural drawings required 2 full stories of shoring and 1 story of reshoring while a concrete slab was being cast. The NBS team concluded that the estimated location of forms, shores, and reshores at the time of the collapse was as shown in Fig. 6, with all formwork removed on sections 1-3 of the 22nd floor and little if any reshoring on that floor (Leyendecker and Fattal 1977, pp. 18-31).

Some workers said that all of the shoring was removed on both floors, some said that only some was removed, and others believed that all was still in place at the time of collapse (Leyendecker and Fattal 1977. p. 18). However, the statements of one worker gave the investigators a good idea of the state of the forms at the time of the collapse. Leyendecker and Fattal (1977, p. 31) reported "One workman indicated that, at the time of the incident, he was placing reshores in section 3 of the 21st story and that some reshores were present when he started working. Prior to the incident, all the reshores fell out (except those in the balcony areas). This is consistent with what would be likely to occur if the forms had been removed in the story above." If the shoring had been removed in the 22nd floor, the 22nd floor slab would have been relieved of its previous loads. With less loading, the deflection would have decreased in the slab, causing the reshores on the 21 st floor to fall out.

The overall condition of the formwork was also evaluated. After the collapse, much of the remaining lumber was found to be in poor condition or out of plumb, and thus in violation of OSHA. Some of the lateral bracing was not properly connected to the formwork (Leyendecker and Fattal 1977, pp. 21-26).

Schlager (1994) noted that the OSHA regulations in effect at the time required that for floor spans over $(6.1 \mathrm{~m})(20 \mathrm{ft})$, forms needed to be left in place for at least 10 days of temperatures exceeding $10^{\circ} \mathrm{C}\left(50^{\circ} \mathrm{F}\right)$.

\section{Concrete Strength and Strength Development}

Results of standard ASTM C39 concrete cylinder tests showed adequate strength at 7 and 28 days. However, these were laboratory tests, with cylinders stored at a controlled temperature. Particularly in cold weather, laboratory tests do not correspond to the strength of the concrete in place in a structure. OSHA regulations required fieldcured cylinders, stored at the same temperature as the structure, to verify the strength of the structure before removing shores and formwork. As part of the investigation, 100-mm (4-in.) diameter cores were obtained from the structure. These also showed that the 


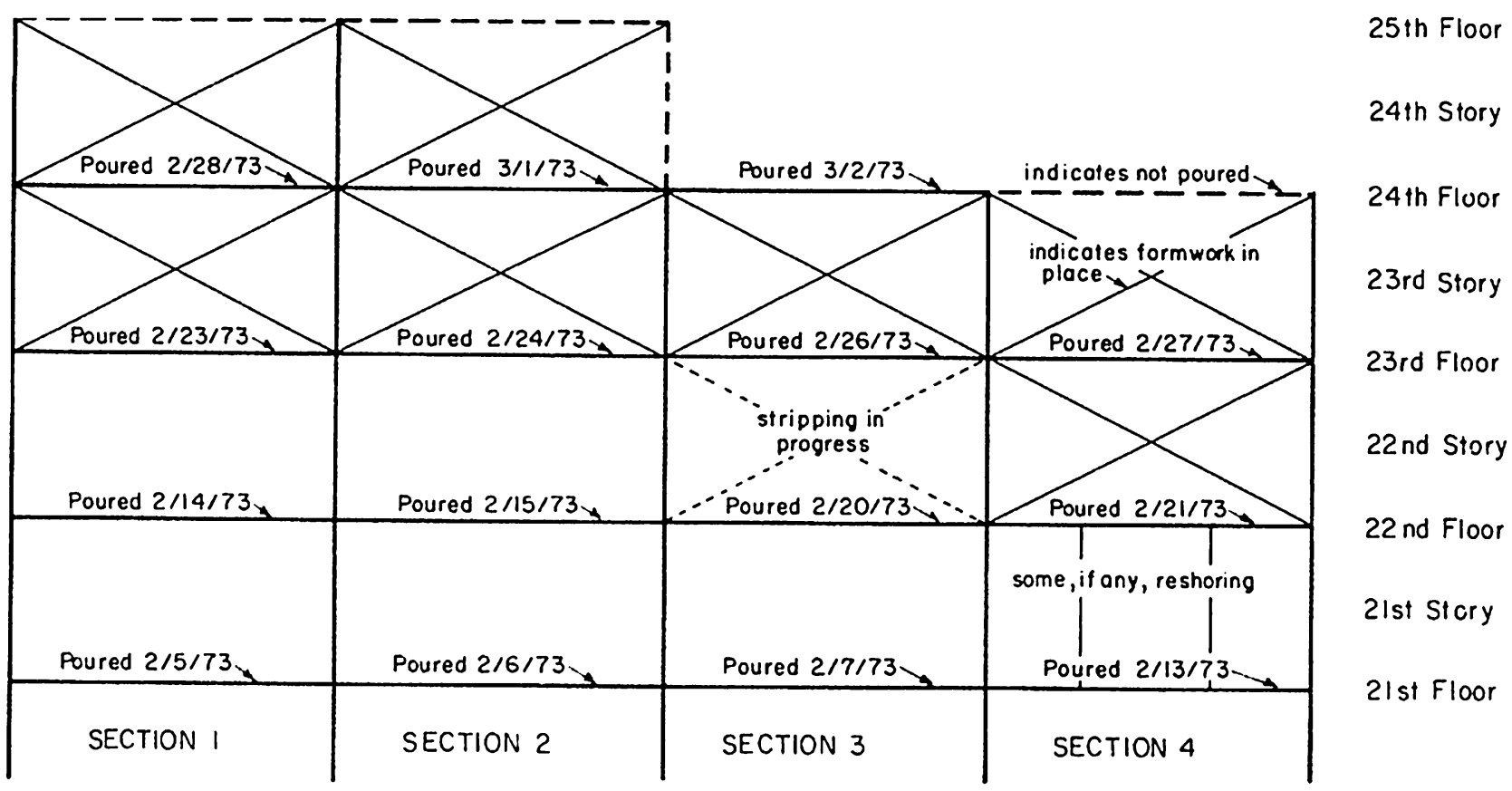

LOOKING NORTH

Fig. 6. Estimated location of forms and reshores at the time of the collapse (Leyendecker and Fattal 1977, p. 30)

quality of concrete delivered to the project was sufficient to produce adequate strength (Leyendecker and Fattal 1977, pp. 57-59).

It is well known that cold weather delays gains in concrete strength. The maturity method (ASTM 2011) can be used to account for this effect. The calculation may be performed in terms of timetemperature factor (TTF) or equivalent age. To calculate the TTF

$$
M(t)=\sum\left(T_{a}-T_{0}\right) \Delta t
$$

where $M(t)=$ time-temperature factor at age $t$, in degree-days or degree-hours; $\Delta t=$ a time interval, in days or hours; $T_{a}=$ average concrete temperature during the time interval $\Delta t$; and $T_{0}=$ datum temperature, typically taken as $-10^{\circ} \mathrm{C}\left(14^{\circ} \mathrm{F}\right)$ (ACI 2003).

To calculate equivalent age

$$
t_{e}=\sum e^{-Q\left(\frac{1}{T_{a}}-\frac{1}{T_{s}}\right)} \Delta t
$$

where $t_{e}=$ equivalent age at specified temperature $T_{s}$, in days or hours; $Q=$ activation energy divided by the gas constant (kelvin), often taken as 5,000 K for concrete made with ASTM Type I cement; $T_{s}=$ specified temperature, typically $296 \mathrm{~K}$ or $23^{\circ} \mathrm{C}\left(73^{\circ} \mathrm{F}\right)$, generally the temperature of laboratory cured cylinders; and other variables are as previously defined (ACI 2003).

However, it was February, and the ambient temperature ranged from -2 to $11^{\circ} \mathrm{C}\left(28-52^{\circ} \mathrm{F}\right)$. This meant two things. First, the number of days when construction was suspended because of low temperatures was usually at least 1 day per week, and secondly, it would take more time for the concrete to gain its required strength. For example, sections one, two, and three of the 21 st floor were placed on February 5th, 6th, and 7th, respectively. However, the fourth section of the 21 st floor was not placed until a week later on February 13th.

Temperatures recorded at National Airport before the collapse suggested that the average air temperature was $5.6^{\circ} \mathrm{C}$ for the $22 \mathrm{nd}$ floor and $7{ }^{\circ} \mathrm{C}$ for the 23 rd floor (42 and $45^{\circ} \mathrm{F}$, respectively) (Leyendecker and Fattal 1977, p. 60). The temperature history is shown in Fig. 7. Concrete cured at $\left(5.6^{\circ} \mathrm{C}\right)\left(42^{\circ} \mathrm{F}\right)$ for 1 week would have a $\mathrm{TTF}=(5.6+10) \times 7=109^{\circ} \mathrm{C}-$ days $[(42-14) \times 7=$ $196^{\circ} \mathrm{F}$ - days]. In contrast, concrete cured at the standard laboratory temperature of $23^{\circ} \mathrm{C}\left(73^{\circ} \mathrm{F}\right)$ would have a $\mathrm{TTF}=(23+10) \times$ $7=231^{\circ} \mathrm{C}-$ days $\left[(73-14) \times 7=392^{\circ} \mathrm{F}-\right.$ days $]$. In other words, at $5.6^{\circ} \mathrm{C}\left(42^{\circ} \mathrm{F}\right)$, concrete takes about twice as long to gain strength as at standard laboratory temperature.

In terms of equivalent age, $5.6^{\circ} \mathrm{C}\left(42^{\circ} \mathrm{F}\right)=279 \mathrm{~K}$

$$
t_{e}=\sum e^{-5,000\left(\frac{1}{279}-\frac{1}{296}\right)} \times 7=2.5
$$

Although the two formulas give slightly different results, it is reasonable to assume that at 7 days the concrete in a structure at an average temperature of $5.6^{\circ} \mathrm{C}\left(42^{\circ} \mathrm{F}\right)$ would be roughly equivalent to that of laboratory cylinders at $2-1 / 2$ to $3-1 / 2$ days.

The concrete contained calcium chloride accelerating admixture, at a rate of $2 \%$ by weight of cement, to counteract low temperatures. It is estimated that the strength of the 23rd floor slab concrete was approximately 6.6-9.9 MPa (960-1,440 psi) (Carino et al. 1983).

Throughout the winter, however, construction of 23 floors had proceeded without any evident problems. At some times, the two floors supporting a freshly placed slab had a combined age of only 10 days of equivalent age when considering maturity (Schousboe 1976).

\section{Structural Analysis}

At the time of the collapse, three-dimensional elastic finite-element (FE) analysis using computers was still a relatively new technology. The NBS investigation team used FE analysis to evaluate the slab stresses in the region where the collapse occurred, using beam and plate elements. Stresses were compared with the provisions of ACI 


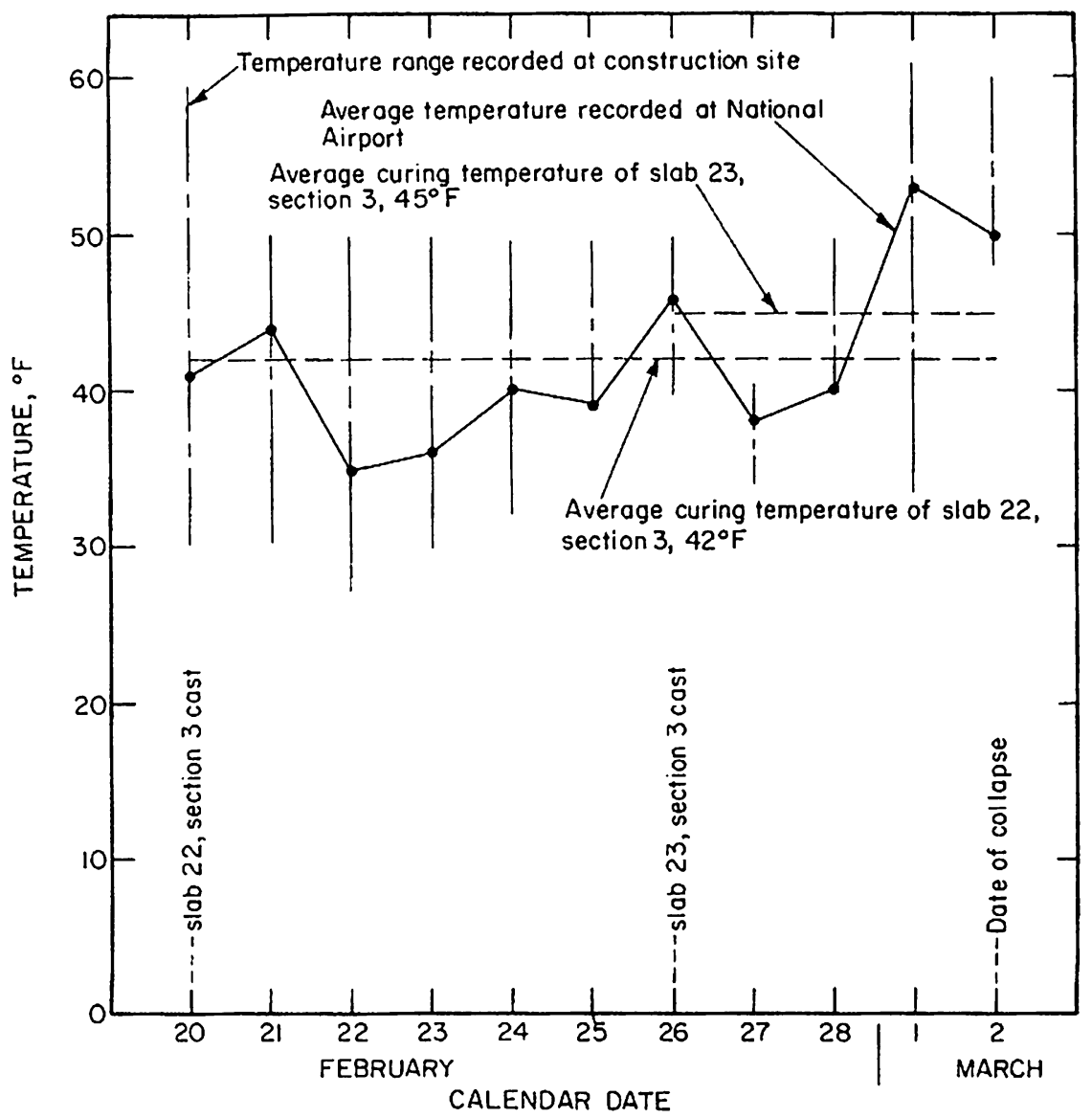

Fig. 7. Temperature history (scale $0^{\circ} \mathrm{F}=-18^{\circ} \mathrm{C}$ and $60^{\circ} \mathrm{F}=15.6^{\circ} \mathrm{C}$ ) (Leyendecker and Fattal 1977, p. 63)

318-71 (ACI 1971). Three different cases were analyzed, with different shoring and concrete conditions. Yield line analysis was also used. The results showed that even with low-concrete strength, a flexural failure of the slab would be unlikely. However, under any of the cases where shores had been removed, a punching shear failure of the slab would probably occur. Once punching shear occurred at any one column, the collapse would rapidly propagate as other slab-column joints became overstressed. There was no indication that the crane was a contributing factor to the collapse (Leyendecker and Fattal 1977, pp. 65-83).

It should also be noted that by the ACI code (ACI 1971), sandlightweight concrete has a $15 \%$ lower shear strength than conventional concrete for the same compressive strength. The most critical locations for punching shear were found to be at columns 67, 68, 83, and 84 (Carino et al. 1983).

\section{Findings from the National Bureau of Standards Investigation}

The NBS team concluded that the most likely cause of the collapse was a punching shear failure of the 23rd floor slab. The two factors that contributed to this were premature removal of shores below the 23rd floor slab, and the low strength of the 23rd floor concrete in the area supporting the weight of the 24th floor slab (Carino et al. 1983). Construction did not adhere to the engineer's requirements that were shown in a note on the structural drawings, which were "slab being poured to be shored for two floors and backpropped at center of span each way and at center of bay on next floor down," or the architect's specifications requiring "in call cases, two floors shall be fully shored." (Leyendecker and Fattal 1977, p. 85). Another investigation was carried out that agreed with the findings of the NBS team (Schousboe 1976).

The NBS team also found other instances of failure to comply with OSHA regulations. These included premature removal of 22nd story shores and failure to use field-cured concrete cylinders to ensure that the concrete had achieved sufficient strength before removing shores and forms. The shoring did not have proper lateral bracing, and some of it was out of plumb and damaged, although this probably did not contribute to the collapse. Inspection that should have noted the problems was either not done or the corrections were not made. Some deviations in the crane supported lengths were also found, but these probably had no bearing on the incident (Leyendecker and Fattal 1977, pp. 85-86).

\section{Legal and Ethical Implications}

The developer was ordered to temporarily halt construction, and a subcontractor was fined $\$ 300$ for improperly shoring freshly poured concrete. At the time, Battiata (1982) noted that company officials refused to discuss the incident.

A number of court cases resulted from this collapse. Most were filed within a year or two of the collapse. A criminal trial was the first to reach the courts. The vice president of the concrete firm was tried for manslaughter, for ordering removal of the formwork. The defendant did not testify, and the case resulted in a hung jury; the jury could not be sure that he had ordered removal of enough of the formwork to cause collapse (Fairweather 1975). 
The concrete subcontractor paid less than $\$ 20,000$ in fines, despite the fact that the collapse had caused $\$ 8$ to $\$ 10$ million in damages, in addition to the deaths and injuries (Schlager 1994).

Next, the Commonwealth of Virginia's Workmen's Compensation legislation provided benefits to the injured and the survivors of those killed. As in many states, the benefits were far from adequate. For example, a quadriplegic might get as little as $\$ 85$ a month for life (Fairweather 1975).

The Worker's Compensation legislation provided immunity to subcontractors and in most cases, the general contractor, so they could not be sued. However, design professionals such as architects and engineers were not protected (Fairweather 1975).

Therefore, one of the injured construction workers later sued the architect and engineer for $\$ 500,000$. The suit was successful, and the plaintiff was awarded the $\$ 500,000$ at the expense of the engineer and architect. The outcome caused considerable concern to the architectural and engineering professional societies (Franklin 1975). The judge later found the amount excessive and cut it in half (Fairweather 1975).

The designers were blamed for not visiting the project site to inspect the construction, despite the fact that it was not part of their scope of work (Schlager 1994; Carper and Feld 1997). As Carper (2001) noted, "The architect and engineer were thus held responsible for the collapse, even though their explicit specifications for required shoring were not being implemented at the site."

Kaminetzky (1991, p. 67) noted that the "collapse raised the issue of the extent of the engineer of record's responsibility for the success and safety of formwork design and inspection. While the engineer's contract specifically stated that he had no responsibility for field inspection, nevertheless a jury found him negligent. This was so because the pertinent code required that 'a competent architect or engineer' must provide supervision 'where requested by the building official'." Often, owners are not willing to pay engineers for the site visits. Some jurisdictions now require owners to pay for inspection.

\section{Educational Aspects}

Schlager (1994) believed that this collapse called attention to some endemic problems of the U.S. construction industry. The first is that project contractors and subcontractors are responsible for temporary works, such as formwork and shoring, although they may not know much about construction loading or structural design. The project structural engineers, who may have that knowledge, are normally not involved in the design of temporary works. A second is that the field implementation of a design depends on construction quality control, and the degree of care in inspection can vary from project to project. The third is that excessive speed of construction can be dangerous. The Portland Cement Association (PCA) and the ACI both used this case to improve building codes and structural safety. Kaminetzky (1991, p. 67) cited six lessons from this case:

- The contractor should be responsible for preparing formwork drawings, including shores and reshores;

- The contractor should prepare a detailed concrete testing plan for stripping forms, including cylinder tests;

- Inspectors and other quality control agencies should verify that the contractor performs the previous two items;

- The Engineer of Record (EOR) should make sure he/she provides the contractor with all necessary design load data and other unique project information;

- Uncontrolled acceleration of formwork removal may cause a total or partial collapse; and

- Continuous top and bottom slab reinforcement is necessary around the columns. Continuous reinforcement provides overall ductility.
If the contractor uses cylinder tests to determine when to strip forms during cold weather, the cylinders should be stored at the same ambient temperature as the structure. This will prevent overestimation of the in-place concrete strength.

This case study is of relevance to a number of engineering courses. For a course in concrete materials, it illustrates how the strength gain of concrete is hampered in cold weather. Courses in construction can also use this collapse to indicate the importance of structural integrity of formwork and of control of shore removal and reshoring.

\section{Conclusion}

"The NBS investigation concluded that the probable cause of the collapse was a punching shear failure of the 23rd floor... The premature removal of forms supporting the 23 rd story slab when the concrete of that slab had a relatively low strength produced shear stresses in excess of the concrete capacity at the time of the incident. . Most of the eyewitness reports indicated deflection in the 23rd and 24th story slabs [varying from 6 in. to $2 \mathrm{ft}(152 \mathrm{~mm}$ to $0.6 \mathrm{~m})$ ] which increased over a 15 or $20 \mathrm{~min}$ time period before failure... The loss of support from any one of these columns led to overstressing of the slab around the remaining columns and the failure propagated through the 23 rd floor until a stable configuration remained. The accumulation and impact of falling debris from the collapsing 23rd and 24th floors overloaded the 22nd floor slab and induced the progressive collapse of successive floors down to the ground" (Carino et al. 1983, p. 41).

Schousboe (1976) concluded that "The errors committed on the Skyline Project at Bailey's Crossroads have all been previously encountered in the history of construction failures. The structure was nothing out of the ordinary; this type of building had been successfully erected many times all over this country. The failure was conceived with a human decision and order to remove formwork without a well-founded estimate of the strength attained by the concrete, and was born when the order was carried out."

Following this incident, Fairfax County, Virginia, was one of the first jurisdictions to adopt a formal critical structures program. These programs required preconstruction conferences to define responsibilities before work begins. The determination of critical structures is based on type of construction, building type, and height, such as posttensioned buildings or structural steel buildings over 3 stories in height ("Inspection programs" 1987).

Despite the fact that this collapse occurred nearly four decades ago, the lessons learned are still relevant. Formwork collapses still occur, although usually on a smaller scale. Safe control of concrete construction still requires a knowledge of concrete strength gain, and of proper formwork design and proper control of shoring removal and reshoring operations.

\section{Acknowledgment and Disclaimer}

This material is based upon work supported by the National Science Foundation under Grant No. 0919487. Any opinions, findings, and conclusions or recommendations expressed in this material are those of the author(s) and do not necessarily reflect the views of the National Science Foundation. This case study was originally drafted by the first author as an Honors thesis as part of the requirements of Cleveland State University's Undergraduate Honors program. The helpful comments of the anonymous reviewers are also acknowledged. Thanks to Nick Carino, formerly of NIST, for providing Figs. 1-4. 


\section{References}

American Concrete Institute (ACI). (1963). "Building code requirements for reinforced concrete." ACI 318-63, Detroit.

American Concrete Institute (ACI). (1971). "Building code requirements for reinforced concrete." ACI 318-71, Detroit.

American Concrete Institute (ACI). (2003). "In-place methods to estimate concrete strength." ACI 228.1R-03, Farmington Hills, MI.

American Concrete Institute (ACI). (2004). "Guide to formwork for concrete." ACI 347-04, Farmington Hills, MI.

ASTM. (2011). "ASTM C1074-11 standard practice for estimating concrete strength by the maturity method." ASTM International, West Conshohocken, PA.

Battiata, M. (1982). "Baileys Crossroads: Patchwork of bungalows, skyscrapers." Washington Post, July 10, B1.

"Building wreckage will be dismantled." (1973). New York Times, Mar. 4, 117.

"Bureau's failure studies aid standards work." (1981). Engineering NewsRecord, Oct. 22, 1981, 13.

Carino, N. J., Woodward, K. A., Leyendecker, E. V., and Fattal, S. G. (1983). "A review of the Skyline Plaza collapse." Concrete Int., 7(5), 35-42.

Carper, K. (2001). "Why buildings fail." National Council of Architectural Registration Boards, Washington, DC.

Carper, K. L., and Feld, J. (1997). Construction failure, Wiley, New York, 242-245, 271-274.
Delatte, N. J. (2009). Beyond failure, ASCE Press, Reston, VA.

Fairweather, V. (1975). "Bailey's Crossroads: A/E liability test." Civil Engrg., 45(11), 58-59.

Franklin, B. A. (1975). “\$500,000 awarded in building collapse.” New York Times, Jan. 14, 19.

Hurd, M. K. (2005). Formwork for concrete, 7th Ed., American Concrete Institute, Farmington Hills, MI.

"Inspection programs plan for responsibility." (1987). Engineering NewsRecord, Aug. 27, 1987, 15.

Kaminetzky, D. (1991). Design and construction failures: Lessons from forensic investigations, McGraw-Hill, New York.

Leyendecker, E. V., and Fattal, S. G. (1977). "Investigation of the Skyline Plaza collapse in Fairfax County, Virginia." Dept. of Commerce, National Bureau of Standards, Institute for Applied Technology, Center for Building Technology, U.S. Govt. Printing Office, Washington, DC.

Schlager, N. (1994). When technology fails: Significant technological disasters, accidents, and failures of the twentieth century, Gale Research, Inc., Detroit, 277-282.

Schousboe, I. (1976). "Bailey's Crossroads collapse reviewed." J. Constr. Div., 102(2), 365-378.

"Six killed as a crane drops through Virginia building." (1973). New York Times, Mar. 3, 1973, 16.

Wight, J. K., and MacGregor, J. G. (2012). Reinforced concrete: Mechanics and design, 6th Ed., Pearson, Upper Saddle River, NJ. 